\title{
Socio-economic and Socio-political Effects of Emigration on the Sending Countries
}

\author{
Magdalena Bonev \\ Walltopia Austria GmbH, Vienna, Austria
}

\begin{abstract}
Migration is one of the most prominent phenomena in these ultimate years. It has brought some good consequences and economic development, but also a number of socio-economical and socio-political problems, such as decreasing population in the sending countries, brain drain, labour market shortages, etc. This paper focuses on the reasons why people emigrate from their countries of origin and what effects bring their emigration to the national economy. The purpose of the paper is to explain the emigration impact on the labour market in the sending countries, the phenomenon "brain drain" and its effects, the impact of the remittances, and the importance of Diasporas and return migration for the countries of origin.
\end{abstract}

Keywords: emigration, effects, developing countries, sending economies

\section{Introduction}

The study of socio-economic and socio-political effects of migration is complicated subject, having in mind not only the effects for the receiving country, but also for the sending one. It requires knowledge about the positive and negative aspects of those effects on both sides of migration based on the individual, local, national, and international level.

The net emigration is causing a dramatic decrease in the number of the population in the sending countries and a fall in the country's labour supply. Much theoretical studies state that the positive and negative effects of the emigration can never be the same for all the individuals in the sending coutry. To identify the effects-gains and losses to emigration-we need to first clarify whether the emigrant's well-being and welfare are going to take part in the scenario. One of the early key hypotheses, examining migration states that emigrants are leaving their home lands, driven by the desire for a better living and higher standard of life (Todaro, 1996; Sjaastad, 1962; Harris \& Todaro, 1970). One of the leading factors, determining the outcomes of the emigration, is related to the length of emigration, whether it is going to be permanent or temporary. When the emigration is being temporary, it can be assumed that the emigrant's income is going to lead to a positive outcome for the country of the origin. On the other hand, if we study a case, where the emigration is permanent, we cannot conclude that the outcome will be for sure the same for the sending country. Unfortunately, most of the time, the objects of the study for many authors and analysers are not aware, whether they are going to stay temporary or they will settle down permanently before they migrate. A common practice in nowadays is that the intention of the people leaving is one at the beginning of their journey, but it changes

Magdalena Bonev, Ph.D., Walltopia Austria GmbH, Vienna, Austria.

Correspondence concerning this article should be addressed to Magdalena Bonev, Migazziplatz 5/32, Vienna 1120, Austria. 
with the time. It seems that there is a positive correlation between the time spent in the new country and the idea of settling there. The more the person stays away their country of origin, the better the chances are for them to change their mind and consider permanent residence.

The effects of emigration will also depend on the type of the economic in the sending country (whether it is small and open to international trade), the occupations that are being left behind, the remittances, the personal qualification and education (whether emigrants are skilled or unskilled), and the probability of return migration.

\section{Effects of Emigration on the Labour Market in the Sending Country}

The empirical data shows that in the traditional countries of emigration, as consequence of the number of emigrants crossing the borders the levels of unemployment are going low, the so-called "export of unemployment" phenomenon. As a result of the lack of working force, the wages are rising. However, labourer's migration is leading to some negative outcomes for the local labour market. For example, in certain industries, like construction and manufacturing, the number of the qualified and skilled labour force is being significantly reduced. These tendencies are common and most likely to occur in the recently joined EU countries, more specifically Eastern European ones. In many factories, the huge demand on skilled employees is becoming a great challenge for some of the owners and business managers. They also state that those circumstances can cost their company positions in the market and even company existence. The shortage of labour force is increasing dramatically in the sending countries that are experiencing structural imbalance in the labour market. This imbalance is making the task of filling those caused by the emigration "gaps" look impossible. However, assuming that the emigration will result in a higher salary rates, attracting more employees in the certain area, it can assumed that not only the wages will raise, but also employers will be willing to provide training and qualifications for their workforce. The impression of a negative emigration effect can turn in to an advantage in long-term period, affecting both sides of the employment.

\section{Effects of Emigration of Skilled Labour-Brain Drain}

When skilled labour emigrates-the so-called "brain drain" phenomenon, the impact on the source country is often considered to be negative. There are couple of reasons for that. First of all, the country of origin is losing the return of its investment in human capital, for example, free education and all other expenses that are being provided throughout the period of raising "the emigrants" when they were growing up. Second of all, highly-educated population will not only get a personal income return by default, but they will also get a high social contribution, such as higher skills, higher wages leading to a higher income taxes, decrease of the child death rates, decrease of the fertility rates, better social and political commitment, voter awareness, etc. On the other hand, when it comes to deciding to emigrate, potential emigrants account for the private gains, perspectives, and outcomes, but will not take into consideration the public and social ones.

The effect of "brain drain" has a specifically negative reflection on the developing countries, where we are not only talking about "brain drain", but for a classical "brain waste" (Okolski, 2006; Kaczmarczyk \& Okólski, 2005). Empirical studies in Eastern European countries prove that the foreign companies, investors in the local markets are experiencing serious problems when trying to find and hire skilled candidates.

Many authors' attention is caught by the fact that whether the emigration of highly qualified labour force has a negative impact is not as simple as the reasons seem to indicate. First, the public investment in human capital may be relatively small. In many cases, much of the expenses related to the education might have been 
paid by the individual or by their family. In fact, individuals may invest in human capital aiming emigration at first place, earning the return on investment in the country recipient and retrieving part of the income gained in the foreign country into the homeland. In the given situation, the return on the investment may come in the form of remittances, sent by the emigrant. Often the amount being sent monthly is exceeding the potential income of the individual if they have not decided to emigrate. Taking into consideration that the emigration could be temporary, rather than permanent, the return of any public investment may come in the form of physical capital that the emigrant returns when he/she comes back in the country of origin. Last, but not least stays the fact that the loss of any social returns on investment in human capital, invested by the public sector, indicates a greater problem than the "brain drain". The fact that the individual will only take into consideration their own personal outcomes of the effect caused by their emigration and will not think about the reflection of it on social and public outcomes, suggests that the society is not investing enough in developing the country. There are certain forms of control and prevention of the emigration that would limit the "brain drain", but they will not be a solution to the problem caused by the lack of investments.

The discussion suggests that the losses to the source country will be positively related to the amount of emigrant's human capital investment that is paid by the public sector. However, such losses will be offset by any remittances sent by the emigrant, who left his/her country of origin, or by any physical capital that returns with the emigrant. In fact, as noted by Lucas and Stark (1985), families with poor access to capital markets may invest in their children, so they can emigrate and later remit some funds.

\section{Remittances Impact on Sending Economy}

Some of the emigrants are sending part of their income to relatives in the country of origin. The money retrieved in the sending country partly or fully compensates the lost income in the household because of the emigration. As noted by Stark (1991), the emigration and remittances may be jointly determined by the family as a way of family income diversification. Families insure by spreading "household members across markets, where income fluctuations are not positively correlated" (Lucas, 1988, p. 126).

Another interesting issue is whether the money transfer is being used for consumption or the exact opposite, being invested or accumulated on a savings account/investment. Kindleberger (1967, p. 94) and Castles and Kosak (1973) all suggested that the foreign financial income, which is being used for domestic needs, are not contributing enough to the development of the sending country. Having in mind the statements above, it can be assumed that the use of the remittances for financing the personal use of the individual, rather than investing, is a negative aspect of the emigration.

However, empiric research outlines the significant effect of remittances on the developing economies in various ways. The main debates about the impact of remittances on growth refer to the use of remittances for productive investment that would contribute to long-run development. But impact on economy should be viewed not only from the point of view of remittances-investment relationship. In fact, remittances can affect positive economy in some of the following ways:

- Management of remittances by bank;

- Extension of investment credit allowed by the increase in the liquidity of banks from remittance deposits;

- Investment in human capital in the form of spending on certain consumption items as education, health, etc.;

- Smoothing income inequality in short-term and diversification;

- Growth in investment as a result of the multiplier effects of spending on consumption; 
- Influence disposable income for investments, savings, and consumption;

- Decreasing poverty, especially in developing countries with high remittances to GDP flows.

Money transfers reach directly the households that need it. As a result, it has to be mentioned that whatever needs are addressing, be it consumption, investments, debt reimbursement, or covering survival expenditure in general, remittances represent an undoubted benefit, being able to satisfy directly household needs.

\section{Social and Socio-political Effects of Emigration}

A serious problem, caused by the increased levels of migration flows, is the depopulation of certain areas of the countries, especially regions that are close to the state borders. Combined with the typical for these regions low mobility of the human capital, the depopulation leads to dramatic regional differences, also in terms of the unemployment levels. In theory, one can expect that the experience and the "adventures" of the emigrants, representing the most mobile part of the population, could possibly contribute to increase the local population's mobility.

One of the significant emigration effects is the rising labour market reforms opportunity for the sending country. If the market is facing high levels of unemployment, this means that there is structural market deficiency observed. Given those circumstances, it will be hard for the source country government to make any reforms. On the other hand, steady labour market can provide an opportunity of making the necessary adjustments.

One of the main social issues in the sending economies caused by the increased emigrational flows and their age and gender specifications is the separation of the family and in many cases the elders left behind. Many women are separated from their partners and children suffer too from the absence of their fathers. Perhaps, one of the most serious problems concerns elderly people, who lost their family and social support. There are many emigrants strategies that include the old people "in the plan" of going and settling in the receiving country. The parents follow their children abroad to provide childcare for their grandchildren, enabling both the working-age parents to engage in paid work. Unfortunately, there are also plenty of cases with elders left behind in the small villages. The last phenomenon is called "elderly orphans". Regardless of the fact that the remittances make the social discomfort bearable enough, the lost of the family (children and grandchildren) takes part in their psychological and emotional self-esteem.

Other evidences show that in some cases children are being left in the country of origin and being raised

by their grandparents. The idea behind is providing better future for the youngsters. Even though the intentions are completely innocent, this scenario often ends in a situation where the child becomes spoiled or problematic. Many kids in that situation drop out of school. Those social effects correlate directly with the future return on human capital investment and economic development of the source countries.

\section{Effects on Sending Country Caused by the National Diasporas Abroad}

The subject of national Diasporas and the issues around it are being neglected for years. With the expansion of emigration flows, they took the media and recently even the politics attention, especially in the developing countries. The most popular representation of Diaspora is very shallow and unsophisticated. The opinion and knowledge about the Diaspora in the sending countries is mostly influenced by the answers of some certain questions, like "Did they succeed 'there' or not?", "Do they love their country?", "Do they visit 
back or not?". The expectations from the emigrants communities is to support their families by sending money back home, but not to take part in decisions on any political or other issues at home or even have an opinion on it. A generalization, like this, prevents an adequate political strategy of getting the Diaspora involved in the economy in the country of origin and also getting the best of their experience abroad.

One of the positive outcomes that could be derived from the emigration of the highly qualified people is gathering them in one well-educated national Diaspora. It has already been mention that the individual contribution to the sending country is mostly related to the financial support to the family. However, the contribution from the Diaspora would have a bigger influence. Presented as a single idea, regardless of the position and the education of the individual, it will not be able to take place in a decision in the country of origin. But the Diaspora would be able to use the accumulated opinion and influence the processes not only in the source county, but also in destination country. China, India, and Taiwan, for example, are some of the countries accomplishing good results using their Diasporas in the national further development. All of these countries have been establishing businesses and educational systems that include their communities abroad and they are protecting their national interests abroad. One of the factors determining the participation of the Diaspora in the national issues is the trust in the government in the country of origin. Corruption is one of the first associations with the home government for many of the emigrants from the traditional source countries That seems to be one of the reasons why people abroad are more willing to support people non-related to an organisation regardless of whether they are part of the family or not. To succeed in any of its initiatives, the country needs to establish trust in its government. Here are some of the suggestions of a good politics and ways of achieving that:

- Acknowledgment of the emigrant's contribution to the country;

- Establishing a systematic support, protection, and stepping in for the rights of the emigrants and their families;

- Contributing and supporting the expansion of the national culture in the foreign countries;

- Social and intellectual network development.

\section{Return Migration}

Part of the emigration is not permanent, but temporary. Usually emigrants that are returning home, invest in their future back in the sending country (in most of the cases by starting own small busness). It seems that they accomplish more for a short period of time abroad and it is most likely that they would not be able to do this if they have not left their country of origin.

Some of the developing sending countries, for example, East European ones, will continue to record higher mortality rates, lower fertility rates and higher level of emigration rather than immigration (net emigration countries). The demand on working force will continue to rise, and thus, the return migration will play an important role in the future economic development of these countries. Many social benefits can attract the emigrants to return, for example, the ability to transfer the accumulated pension from the foreign country and health insurance. The government politics, managing the temporary migration, could be used to take some opportunities provided by other countries, regarding investment in the young population's abilities and skills-seasonal migration, educational programs, internships, etc.

As a last point of the paper, it is worth mentioning the social consequences of the circular and temporary migration. Even though there are many positive impacts for both the sending country and receiving country, in 
many cases the price paid by the emigrants is significant. They move from one country to another, experiencing different social and cultural standards, stress, isolation, and homesickness. Emigrants are being part of more than one country and at the same time they get confused to which country they belong.

\section{Conclusion}

Sending countries are assuredly gaining many and different aspects of positive and negative effects on them caused by the emigration. Some of the impacts are contributing to the future economic development of the country and the economy, for example, return migration, remittances, and national Diasporas. Others like brain drain, brain waste, labour market shortages, and depopulation cause negative influence on the source country. How the drop in population and labour supply affects the source country's economy is varied. In general, the results would be different in the different countries and they will be depending on the type and size of the local economy. The emigration impact will also relate to the number of emigrants and their personal life, goals, and beliefs.

\section{References}

Castles, S., \& Kosack, G. (1973). Imigrant workers and class structure in Western Europe. Institute of Race Relations, London, Oxford University Press.

Chandavarkar, A. G. (1980, June). Use of migrants' remittances in labour-exporting countries. Finance and Development, 17(2), 36-39.

Domingues Dos Santos, M., \& Postel-Vinay, F. (2003). Migration as a source of growth: The perspective of a developing country. Journal of Population Economics, 16(1), 161-175.

Economic and Social Commission for Asia and the Pacific. (1987). International labour migration and remittances between the developing ESCAP countries and the Middle East: Trends, issues and policies. Bankok: United Nations.

Harris, J., \& Todaro, M. (1970). Migration, unemployment and development: A two sector analysis. American Economic Review, 60(1), 126-142.

Kaczmarczyk, P., \& Okólski, M. (2005). International migration in Central and Eastern Europe-Current and future trends. UN Expert Group Meeting on International Migration and Development, United Nations, New York, 6-8 July (UN/POP/MIG/2005/12).

Kindleberger, C. P. (1967). Europe's postwar growth: The role of labour supply. Cambridge, MA: Harvard University Press.

Lucas, R. E. B. (1981). International migration: Economic causes, consequences, and evaluation. In M. Kritz, C. Keely, and S. Tomasi (Eds.), Global trends in migration: Theory and research on international population movements (pp. 85-109). New York, NY: Center for Migration Studies.

Lucas, R. E. B. (1988). Guest worker emigration and remittances. In D. Salvatore (Ed.), World population trends and their impact on economic development (pp. 125-138). New York, NY: Greenwood Press.

Lucas, R. E. B., \& Stark, O. (1985). Motivations to remit: Evidence from Botswana. Journal of Political Economy, 93(5), 901-918.

Katseli, L. T., Lucas, R. E. B., \& Xenogiani, T. (2006). Effects of migration on sending countries: What do we know? Working Paper No. 250. Pairs: OECD Development Center.

MacMillan, M. J. (1982, March). The economic effects of international migration: A survey. Journal of Common Market Studies, 20(3), 245-267.

Okolski, M. (2006). Costs and benefits of migration for Central European countries. CMR Working papers, Formerly ISS Working papers, Seria; Prace Migracyjne, No 7/65.

Sjaastad, L. (1962). The cost and returns of human migration. Journal of Political Economy, 70(5), 80-93.

Stark, O. (1991). The migration of labor. Basil Blackwell, Cambridge.

Todaro, M. P. (1996). Economic development (6th ed.). Addison-Wesley 1740. 